\title{
Independência dos Estados Unidos, de Ralph Emerson
}

\author{
Rodrigo Alva
}

Autor, poeta e filósofo norte-americano, Ralph Waldo Emerson nasceu em 25 de maio de 1803, em Boston, Massachusetts. Ele é conhecido como um dos maiores autores, filósofos e pensadores norte-americanos. Em uma viagem à Europa, Emerson teve contato com intelectuais como Thomas Carlyle e William Wordsworth. As idéias desses homens, aliadas às de Platão e aos conceitos do hinduísmo, do budismo e de pensadores da Pérsia, influenciaram no desenvolvimento da filosofia do transcendentalismo.

As raízes do transcendentalismo se apresentam na filosofia transcendental de Immanuel Kant adotada pelos intelectuais ingleses como alternativa ao chamado sensorialismo de Locke. Os ditos transcendentalistas desejavam dividir sua religião e filosofia em princípios transcendentais que não fossem baseados em experiências sensoriais, mas sim em experiências vindas do interior do espírito ou da mente do ser humano. Kant alegava que todo conhecimento era transcendental, pois não se prendia apenas a objetos, mas também a camadas de nossas mentes. Esse grupo era muito apegado à filosofia alemã, e sempre buscava seguir, de maneira ativa e engajada, os escritos de Thomas Carlyle, Victor Cousin e Samuel Taylor Coleridge, entre outros autores. Os objetivos práticos dos transcendentalistas eram diversos: alguns associavam o movimento 
a uma mudança social utópica; já outros o viam como um projeto individual e idealista - Emerson era adepto desta visão.

Em 1836, Emerson expressou o princípio do transcendentalismo, a unidade mística da natureza, por meio de uma de suas obras, Nature. A publicação desse artigo tornou-se um divisor de águas - o transcendentalismo acabara de receber o status de grande movimento cultural.

"Concord Hymn" é considerada a mais famosa versão literária sobre a independência dos Estados Unidos. Sessenta anos após o evento, Emerson escreveu o poema para a inauguração de um monumento ao lado da famosa ponte em Concord, local onde houve a batalha da independência norte-americana.

\section{Sobre as escolhas do tradutor}

Quando me deparei com esse hino e com a história que o cercava, interessei-me por traduzi-lo. Foi, inclusive, a pedido de um site de história que dei início à tentativa. A princípio pensei em manter um paralelismo entre métrica e rima, passando do pentâmetro jâmbico, característico dos versos de língua inglesa, para uma roupagem mais próxima da nossa língua - como um soneto. Contudo, julguei que, por se tratar da representação histórica do hino, talvez fosse mais interessante mantê-lo o mais intacto possível e apenas tentar transmitir a força e o simbolismo das palavras que procuravam reviver o momento. Tomada tal decisão, busquei então concentrar-me apenas na escolha das palavras, mantendo certo controle sobre as rimas e a sonoridade, porém sem muita preocupação com a métrica. Do início do processo à "versão final", se é que isso existe, foram cerca de dez dias.

Não posso deixar de agradecer aos avaliadores da Cadernos pelas críticas pertinentes e enriquecedoras feitas à tradução quando 
esta lhes foi submetida. $\mathrm{O}$ resultado pode ser analisado a seguir. Certamente devem existir versões mais elaboradas e com outras preocupações estilísticas, mas esta aqui apresentada busca, com sua simplicidade, transmitir a importância do momento.

\section{Concord Hymn}

Sung at the completion of the Concord Monument on April 19, 1836

By the rude bridge that arched the flood,

Their flag to April's breeze unfurled,

Here once the embattled farmers stood,

And fired the shot heard round the world.

The foe long since in silence slept;

Alike the conqueror sleeps;

And time the ruined bridge has swept

Down the dark stream that seaward creeps.

On this green bank, by this soft stream, We set today a votive stone;

That memory may their deed redeem,

When, like our sires, our sons are gone.

Spirit that made these heroes dare

To die, or leave their children free,

Bid Time and Nature gently spare

The shaft we raise them and thee. 
Rodrigo Alva. Independência dos Estados Unidos, de Ralph Emerson

\section{Hino a Concord}

Declamado na inauguração do monumento Concord em 19 de abril de 1836

Na rude ponte que sobre a cheia curvou, Sua bandeira na brisa de abril desdobrou.

Certa vez os fazendeiros em combate ficaram

Aqui, e no mundo ressoou o tiro que deram.

Há muito repousa o antagonista em silêncio,

Bem como o conquistador adormecido.

E essa ponte devastada o tempo varreu

Na direção do mar por entre o ribeirão em breu.

Neste jorro suave, nesta verde margem,

Hoje nós fincamos uma pedra votiva.

Para que sua proeza remir ela possa

Quando, assim como nossos pais, nossos filhos se forem.

Coragem que fez os heróis se arriscarem aqui

A morrer, ou os filhos em liberdade deixar,

Peça à Natureza gentilmente respeitar

O mastro que elevamos a eles e a ti. 